\title{
Environmental Impacts of Shewashok Oil Field on Sheep and Cow Meat Using Vital Trace Elements as Contamination Bioindicators
}

\author{
Mamoon Qader Salih', Rawaz Rostam Hamadamin², Rostam Salam Aziz ${ }^{3}$ \\ ${ }^{1}$ Department of Oil and Gas, Mad Institute, Arbil-Koya Road, Erbil, Kurdistan Region, Iraq, ${ }^{2}$ Department of Basic \\ Education, Koya University, Daniel Mitterrand Boulevard, Koya KOY45 AB64, Kurdistan Region - Iraq, ${ }^{3}$ Department of \\ Geography, Koya University, Daniel Mitterrand Boulevard, Koya KOY45 AB64, Kurdistan Region - Iraq
}

\section{A B S T R A C T}

Ambient environment is built based on the interaction of living and non-living organism and chemical and physical compounds, and thus, oil field emissions, effluents, and its general waste can be a part of environmental condition of certain area. This study is to investigate the environmental impacts of oil field on sheep and cow meat around Shewashok oilfield. It has been performed at the Laboratories of the Department of Medical Microbiology, Koya University, by detecting and measuring heavy metals and vital trace elements as contamination indicators. 20 meat samples of domestic animals (cow and sheep) in both control and affected area were collected for the purpose of detecting the concentration of heavy metals in the animals. The samples dried and digested with concentrated $\mathrm{HNO}_{3}$ and concentrated $\mathrm{H}_{2} \mathrm{O}_{2}$. The concentration of heavy metals of the sample digested domestic animal was determined using inductively coupled plasma-optical emission spectroscopy. This study shows that iron, cobalt, copper, zinc, arsenic, manganese, aluminum, mercury, and chromium were detected in all the meat samples. Overall, this study confirms that the cow and sheep meat are still safe to eat in both locations because only $\mathrm{Al}, \mathrm{Fe}$, and $\mathrm{Hg}$ were found danger in both sheep and cows' meat in comparison with allowed limits of the World Health Organization 2017, and all other trace elements are complying with the global standards.

Index Terms: Cows' and Sheep Meat, Environmental Pollution, Oil Field, Shewashok, Trace Elements

\section{INTRODUCTION}

The Shewashok oil field was discovered in 1930. The first well was drilled in 1960 and the second was drilled in 1978, but, due to political circumstances, oil was not extracted until 1994 where the production was 44,027 barrels/day in that year. Then production reached 140,000 barrels a day by 2016 [1]. A total of 31 wells are drilled, and currently, more wells are

\begin{tabular}{|l|l|}
\hline \multicolumn{2}{|c|}{ Access this article online } \\
\hline DOI: 10.21928/undjst.v3n1y2019.pp1-8 & $\begin{array}{l}\text { E-ISSN: 2521-4217 } \\
\text { P-ISSN: 2521-4209 }\end{array}$ \\
\hline $\begin{array}{l}\text { Copyright @ 2019 Salih, et al. This is an open access article distributed } \\
\text { under the Creative Commons Attribution Non-Commercial No } \\
\text { Derivatives License 4.0 (CC BY-NC-ND 4.0) }\end{array}$ \\
\hline
\end{tabular}

drilling, but the field has rarely been studied scientifically, especially regarding ecological aspects.

Air, water, and food are the basic needs of most of the living organisms to survive. The quality of consumed water, air, and food may transfer to the consumer body organisms. With gas flaring in the oil field, toxic gases and particles are released into the atmosphere [2]. Quite possibly the particles contain heavy metals due to that they are driven from hydrocarbons and come from deep geological layer formations, obviously living organisms consume this contaminated air as the source of their respiration.

Furthermore, diet is the most critical pathway of transferring the trace elements to mammal's organisms and store in the tissues; therefore, laboratory testing of animal tissues can be Corresponding author's e-mail: Rawaz Rostam Hamadamin, Department of Basic Education, Koya University, Daniel Mitterrand Boulevard,
Koya KOY45 AB64, Kurdistan Region - Iraq, E-mail: rawaz.rostam@koyauniversity.org

Received: 20-09-2018

Accepted: 24-01-2019

Published: 25-01-2019 
a vital bioindicator for environmental pollution [3]-[5]. Some Nigerian studies showed that, during drilling, oil production, refining, and gas flaring, harmful elements can add to air, soil, and both surface and groundwater [6], [7]. If air, water, and soil quality is not acceptable by standards, then vegetation, plants, and fruit quality can alter [7]. In general, contamination of air, water, and soil can transfer to plants then to animals by ingestion and then to human. In the study area, a research showed that groundwater is already not complying with national and international standards [1]. However, air, soil, and agriculture crops have not been studied yet.

Not all the trace elements are heavy metal but all the heavy metals are trace elements and toxic out of their limits. Therefore, some of the trace elements are essential for life, although some of them can cause a high risk to the health [8], [9]. In general, the metals can be classified into three main groups: Potential toxic such as cadmium and mercury; probably essential such as manganese and silicon; and essential metals such as cobalt, copper, zinc, and iron [8]-[10]. The toxicity effects are referred to specific types of metals which are not beneficial to human health; contrary, it causes severe toxicological effect if body receives an amount out of safe limit [8]. It may not be easy to prevent intake of trace elements by human, as industries significantly develop on a sustained speed around the world, a large amount of metals streaming into the environment. Moreover, yet, most of the heavy metals are permanently circling in the environment because they are indecomposable materials and these can integrate with daily essentials such as food and water, and hence, they make their way into the human tissues through the food chain [8], [11].

Meat is considered as an essential source of human nutrition. The chemical composition of meat depends on the quality of animal feeding; this may potentially accumulate toxic minerals and represent one of the sources of critical heavy metals [8], [10]. The risk associated with the exposure to heavy metals present in food and food products has aroused widespread concern in human health [11]. However, improvement in food production and processing technology achieved, but food contamination with various environmental pollutants also increased, especially trace elements and heavy metals among them.

In the light what introduces above, the current study aims to evaluate some vital trace elements such as $\mathrm{Al}, \mathrm{As}, \mathrm{Cu}, \mathrm{Cr}$, $\mathrm{Co}, \mathrm{Fe}, \mathrm{Hg}, \mathrm{Mn}$, and $\mathrm{Zn}$ in raw meat of cow and sheep that produced in Iraqi Kurdistan, and it tries to understand their level of danger and toxicity to consumers. The samples were collected from two industrial sites, an area surrounding the
Shewashok oil field and in the north of Erbil. It will compare both samplings together and then evaluate them by considering the WHO standards for heavy metals and trace elements.

\subsection{Study Area}

The samples were collected from north of Iraq in Erbil province Fig. 1. This region is with Mediterranean climates system, having cool, wet winter, and hot and dry summers with mild spring and autumn, and its annual average precipitation is $450 \mathrm{~mm}$ with some variation from the mountains to the plains [12].

Two locations were selected from the province for the sampling: Focused location which is Shewashok oil field (called study area group in this article) in the southeast of Erbil and the second location is in the north of Erbil which is the main arable area and livestock farming of the province. The animals are feeding with available rearing resources in the region that means that the meat quality is affected by the ambient environment condition.

\section{MATERIALS AND METHODS}

The study data collection, preparation, and analysis followed below stages.

\subsection{Sample Collection}

The materials used for the study included field and laboratory materials. The experimental work has been performed at the laboratories of the Department of Medical Microbiology, Koya University. The collected samples from slaughterhouse of Arbil city "control area" and Koya city "study area." 20 meat samples were collected from each cow and sheep of the study area to detect the concentration of trace elements. In parallel, 20 samples have been collected from each cow and sheep of the control area.

\subsection{The Summary of the Samples Collected at Both the Locations}

- Number of samples collected: 80 samples.

- Number of samples collected of the study area sheep and cows: A total of 40 samples "in another word, 20 samples of each."

- Number of samples collected of control sheep and cows: A total of 40 samples "in another word, 20 samples of each."

- Trace element analyzed: Iron, cobalt, copper, zinc, arsenic, manganese, aluminum, mercury, and chromium. 
Maamun Qadir Salih, et al.: Shewashok Oil Field Impacts on Environment

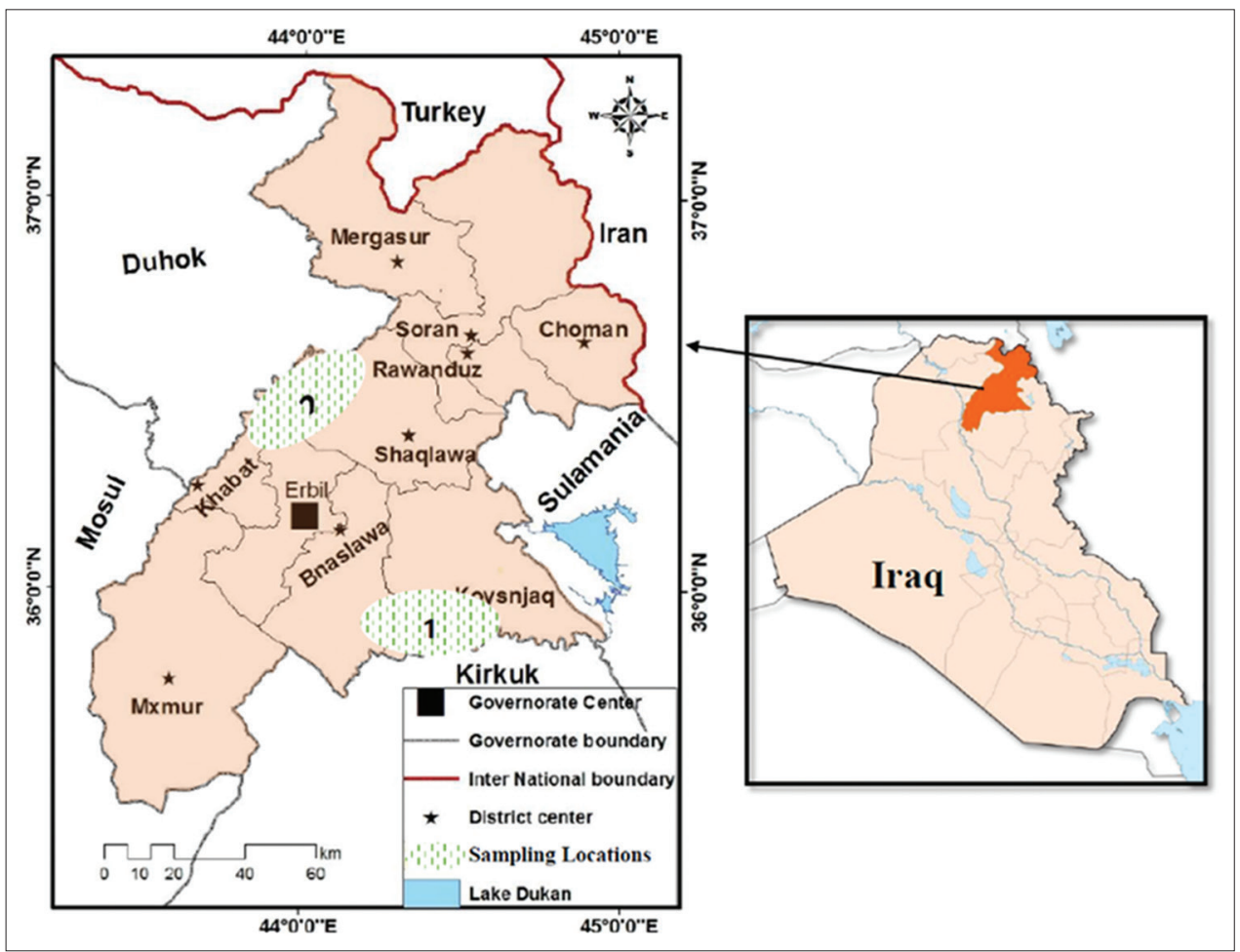

Fig. 1. Study area map with explain sampling locations.

Source: Kurdistan Region of Iraq, Ministry of Planning, Information Directorate and the preparation of maps, map of Erbil in 2016 , scale (1: 250000).

\subsection{Used Materials and Chemicals}

\subsubsection{Material}

Cylinder, funnel, beaker filter paper watch glass, pipette, volumetric flask, conical flask, balance, bottle $(250+500) \mathrm{ml}$ hot plate, oven, centrifuge, hood, gloves, tissues, bio hand (alcohol to cleaning), plastic bags, blade operations, parafilm, bottle to save solution, falcon tube, cuter, and tongue depressor were used.

\subsubsection{Chemical}

Nitric acid, hydrogen peroxide, distilled water, deionized water, vacuum clever for cleaning materials, and inductively coupled plasma (ICP) were used as chemicals.

\subsubsection{Digestion procedure to the determination of trace elements in the sample meat of sheep and cow} animals by ICP-optical emission spectroscopy (OES)

The collected samples were decomposed by wet digestion method for the determination of various metals.

The collected samples were washed with distilled water to remove any contaminant particles. The samples were cut to small pieces using clean scalpel. Samples were dried in an oven at $100^{\circ} \mathrm{C}$.

Weight $1 \mathrm{~g}$ of dried sample, using sensitive balance. Transfer the dried samples into $250 \mathrm{ml}$ digestion beaker or flask. Digest the sample by adding $10 \mathrm{ml}$ of concentrated $\mathrm{HNO}_{3}$ and mix well. Heat the digestion mixture on a hot plate at $100 \pm 10^{\circ} \mathrm{C}$ for $30 \mathrm{~min}$, inside the fume chamber (Hood). Repeat the heating process once more with $10 \mathrm{~mL}$ of the acid. Cool down the mixtures to room temperature, and then, add $2 \mathrm{~mL}$ of concentrated $\mathrm{H}_{2} \mathrm{O}_{2}$. Heat the beaker or flask again carefully, until dryness. Leave to cool down, then dissolve the mixture in distilled or deionized water until obtaining a clear solution. Filter the sample solution through a cellulose filter paper into $25 \mathrm{ml}$ digestion tubes. The filtrate was diluted to $25 \mathrm{~mL}$ with distilled or deionized water and heated the solution to dissolve the precipitate Transfer the samples into laboratory polyethylene bottles and store until analyzed. A blank digestion prepared in the same procedure for the control samples. Finally, analyze the elements in the sample solutions by ICP/ICP-OES. The final measurement volume of the sample solutions should be $5 \mathrm{ml} \mathrm{[13]-[15].}$ 


\subsubsection{ICP-OES}

The well-known ICP-mass spectrometry technique has been used to test the samples at a modern scientific laboratory for heavy metals. Among the trace elements, only 17 critical heavy metals have been examined due to their negative impacts on living organisms [16].

\subsection{Statistical Analysis}

For the first section of this study discussion, data were expressed as mean \pm standard error of mean , and the Statistical Package for the Social Sciences (Version 20) software was used to analyze the results. Differences in mean values between two groups were analyzed by $t$-test. $P<0.05$ was considered to be statistically significant.

\subsection{Comparison of the Study Observations with the WHO Standards for Trace Elements}

For the second section of this study discussion, only study area data (excluding control area in this section) were compared with the WHO 2017 guidelines for trace elements limits to find the level of contamination in our study according to the global scale.

\section{RESULTS AND DISCUSSION}

In recent years, much attention has been given to contamination of food products, among the animal meats. The level of trace elements in meat from different animals depends on some factors such as environmental conditions of the animal grazing location. The obtained results of the current study were divided into two sections to discuss; the first section is a comparison between study area which is Shewashok oil field and control area which is the north of Erbil, whereas the second section is a comparison between the study areas with the WHO standards.

\subsection{First Section: Comparison of Study Area with Control Area}

Table 1 shows that the difference between control and study groups of aluminum in sheep samples is 254.6 and $404.5 \mathrm{ppb}$, respectively, that means the study area is higher than control group by 1.5 times. Table 2 shows that the value of aluminum in cow sample of both control group and study area is 186.2 and $278.7 \mathrm{ppb}$, respectively, again the value of study area is higher than the control group by 1.4 times. Both locations have a similar value for aluminum, but in comparison with the WHO 2017 guidelines which are 200 ppb, both locations are higher than allowed limit that is due to the type of animal diet in both the groups [17].
Arsenic is also very toxic to animals, because it affects their body through gastrointestinal tract and the cardiovascular system. Symptoms of arsenic poisoning in animals include watery diarrhea, severe colic, dehydration, and cardiovascular collapse [13].

Table 1 presents that the value of arsenic in sheep samples of control area and study area is $8.005 \mathrm{ppb}$ and $6.256 \mathrm{ppb}$, respectively, and Table 2 presents that the value in cow samples of control area and study area is $8.015 \mathrm{ppb}$ and $7.478 \mathrm{ppb}$, respectively. Both sample sheep and cows of control group are higher than the study area and it is due to the contamination of pasture by industrial emissions [14]. Previous study shows a high concentration of arsenic in the meat of cattle and goats in Bieszczady mountains [18]. All samples of both locations in this study are within the allowed limit of the WHO which is10 ppb.

Tables 1 and 2 show that the result of chromium in both the locations had high differences between the control group and study area. The value of the control group of both sheep and cows' meat samples showed zero, but the study area location of the samples showed 0.752 and

TABLE 1: Trace element concentration in control and study groups of sheep meat

\begin{tabular}{lccc}
\hline Elements & Control group $(\mathbf{p p b})$ & study group $(\mathbf{p p b})$ & $\boldsymbol{P}$ value \\
\hline $\mathrm{Al}$ & $254.6 \pm 48.51$ & $404.5 \pm 126.3$ & 0.275 \\
$\mathrm{Fe}$ & $1941 \pm 295.2$ & $474.1 \pm 121.2$ & 0.0001 \\
$\mathrm{Hg}$ & $26.12 \pm 0.434$ & $26.91 \pm 0.484$ & 0.229 \\
$\mathrm{Mn}$ & $159.5 \pm 31.21$ & $179.7 \pm 28.88$ & 0.638 \\
$\mathrm{Zn}$ & $1006 \pm 100.9$ & $1080 \pm 128.8$ & 0.654 \\
$\mathrm{As}$ & $8.005 \pm 0.789$ & $7.478 \pm 1.010$ & 0.683 \\
$\mathrm{Co}$ & $0.000 \pm 0.000$ & $0.266 \pm 0.116$ & 0.028 \\
$\mathrm{Cr}$ & $0.000 \pm 0.000$ & $0.752 \pm 0.347$ & 0.037 \\
$\mathrm{Cu}$ & $492.6 \pm 61.65$ & $1038 \pm 253.8$ & 0.043 \\
\hline
\end{tabular}

Results expressed as mean $\pm \mathrm{SE}$

TABLE 2: Trace element concentrations in control and study groups of cow meat

\begin{tabular}{lccc}
\hline Elements & Control group $(\mathbf{p p b})$ & study group $(\mathbf{p p b})$ & $\boldsymbol{P}$ value \\
\hline $\mathrm{Al}$ & $186.2 \pm 31.59$ & $278.7 \pm 41.19$ & 0.08 \\
$\mathrm{Fe}$ & $1356 \pm 154.9$ & $3720 \pm 534.3$ & 0.0001 \\
$\mathrm{Hg}$ & $26.49 \pm 0.455$ & $26.78 \pm 0.585$ & 0.699 \\
$\mathrm{Mn}$ & $104.9 \pm 22.35$ & $110.0 \pm 12.45$ & 0.842 \\
$\mathrm{Zn}$ & $685.9 \pm 90.73$ & $1688 \pm 264.4$ & 0.001 \\
$\mathrm{As}$ & $8.015 \pm 0.812$ & $6.256 \pm 0.950$ & 0.171 \\
$\mathrm{Co}$ & $0.271 \pm 0.127$ & $1.242 \pm 0.344$ & 0.012 \\
$\mathrm{Cr}$ & $0.000 \pm 0.000$ & $6.692 \pm 4.636$ & 0.157 \\
$\mathrm{Cu}$ & $922.2 \pm 268.9$ & $134.3 \pm 28.96$ & 0.006 \\
\hline
\end{tabular}

Results expressed as mean \pm SE

UHD Journal of Science and Technology | Jan 2019 | Vol 3 | Issue 1 
$6.692 \mathrm{ppb}$, respectively, of sheep and cow sample; the high value of chromium in the study area is due to the release of chromium into the environment due to natural gas flaring during oil processing [19], [20]. This result was supported by the assessment of heavy metal pollution and contaminations in the cattle meat [13], [21]; however, the samples of both the locations had a lower value of chromium than allowed limit $50 \mathrm{ppb}$ according to the WHO guideline.

For cobalt, Tables 1 and 2 show that the value between both locations in the sheep meat sample is 0.000 and $0.266 \mathrm{ppb}$, respectively, in control and study group, and for the cows' meat sample, the recorded value in control and study group is 0.271 and $1.242 \mathrm{ppb}$, respectively; the study area was higher than control area by approximately 4.6 times, it might due to soil contamination, also pasture lands is recognized as a source of $\mathrm{Co}$, it can occur as a result of animal treading or soil splash on short pasture during heavy rain [22]. However, all samples of both the locations are within the allowed limit of the WHO which is $3 \mathrm{ppb}$.

Mercury is volatile liquid metal, found in rocks and soils, and also is present in air as a result of human activities as the use of mercury compounds in the production of fungicides, paints, cosmetics, papers pulp, etc. The highest concentrations were found in soils from urban locations; mercury may induce neurological changes and some diseases [23].

Table 1 shows that the sample of sheep meat had a high value of mercury contents of samples in the control and study area ranged between $26.12 \mathrm{ppb}$ and $26.91 \mathrm{ppb}$, respectively, and also the sample of cows' meat like sheep meat had a high amount in both location control group (26.49 ppb) and study area (26.78 ppb). A previous study findings comply with this finding as mercury recorded high in beef meat from Algeria [14].

Zinc is another essential element in our diet, but the excess may be harmful, and the provisional tolerable weekly intake (PTWI) zinc for meat is $700 \mathrm{mg} /$ week/person [21]. The minimum and maximum levels of $\mathrm{Zn}$ were detected in both the location of control group and study area of sheep samples which was recorded between 1006 and $1080 \mathrm{ppb}$ respectively, and for the cows' sample, was recorded 685.9 and $1688 \mathrm{ppb}$, respectively, in both location of control group and study area, and none of the samples exceeded the recommended limit $3000 \mathrm{ppb}$ according to the WHO guideline. Moreover, the difference between both positions of zinc metal is non-significant in sheep samples but for the cows' sample had a highly significant; however, the meat sample of cows and sheep in study area location showed a higher value when compared to control group because of the high intake of zinc by animals, due to several factors, first of all having excessive amounts of zinc in animal's food, pastures lands contaminated with smoke that polluted by zinc, surfaces painted with high-zinc paints where animals could lick them and finally food transport in galvanized containers that already containing zinc when manufactured [24], [25].

Iron deficiency causes anemia and meat is the source of this metal; however, when their intake is excessively elevated, the essential metal can produce toxic effects [26]. Table 1 shows that the iron value of control group and study area for sheep was 1941 and $474.1 \mathrm{ppb}$, respectively, and the amount of the control is more elevated than study group by 4 times, which recorded among the sheep meat samples [8].

Table 2 shows that the value of iron in cows' meat sample was 1356 and $3720 \mathrm{ppb}$, respectively, of the control group and study area, and both the locations are higher than allowed limit $300 \mathrm{ppb}$ according to the WHO guideline. That is due to the type of feeding which contains dry plants that may be very rich with mentioned elements, or the consumed water is containing a high level of Fe.

Tables 1 and 2 show that the value of manganese element in cows' meat sample in control group and study area is 104.9 and $110 \mathrm{ppb}$, respectively, also in sheep meat sample, the amount of manganese of control and study area is 159.5 and $179.7 \mathrm{ppb}$, respectively, and the values of the study area is higher than the control group.

Although copper is essential for good health, the PTWI copper for fresh meat has been proposed as $14 \mathrm{mg} /$ week/ person [13]. However, very high intakes can cause health problems such as liver and kidney damage [25]. Determination of the $\mathrm{Cu}$ content in food is also an important subject concerning human consumption [27], [28].

Table 1 shows that the value of copper element of control group and study area for sheep is 492.6 and $1038 \mathrm{ppb}$, respectively, and the study area is higher than control area by 2.1 times. The results of the present study indicate that the values of copper in the study area were relatively high compared with the WHO guideline. That is, since this metals enter through feed material from burning zoon and transport excuse products, ultimately passage into the tissues and the excessive ingestion of copper by animals could occur in various situations such as grazing 
immediately after fertilization, pastures grown on soils containing high concentration of copper, supply of wheat treated with antifungal drugs containing copper, and pasture contaminated by smoke from foundries [21].

This result is compatible with other studies in countries such as Sweden, as high values of copper were found in the cattle meat [28], [29]. Moreover, about copper, Moreover, Table 2 shows that copper values of the control group and study area is 922.2 and $134.3 \mathrm{ppb}$ respectively for cow's meat. Cows' meat from the control group had a higher value of $\mathrm{Cu}$ concentration compared with the study group. In this study, records of both animals and locations are within allowed limit 1000 ppb of WHO 2017.

In general, both areas are quite similar for cows and sheep because the values are close, which may be result of similarity of the geographic feature and exist no effective physical barrier between both locations.

\subsection{Section Two: Comparing Study Area with the WHO 2017 Standards}

Most of the elements are within the WHO standards such as $\mathrm{Mn}, \mathrm{Zn}, \mathrm{As}, \mathrm{Co}$, and $\mathrm{Cr}$ in both cows' and sheep meat, and only $\mathrm{Cu}$ is just above the WHO limit by 38 ppb in sheep meat samples; however, it is within the standard in cow samples (Table 3). $\mathrm{Al}$ and Fe both are exceeding the WHO guideline, Al by 204.5 and Fe by 174.1 ppb in sheep samples and Al 78.7 $\mathrm{ppb}$ and Fe $3420 \mathrm{ppb}$ in cow samples. Furthermore, Hg is out of the WHO accepted range but with a high significant difference between the samples and the standard value, which is more than 4 times higher than the standard (Table 3).

This simple comparison notes that most of the elements are within the WHO standards such as $\mathrm{Mn}, \mathrm{Zn}, \mathrm{As}$, Co, and $\mathrm{Cr}$, which means that they have no health risks on consumers [30], [31]. Cu which is an essential trace element for a human body is just above the WHO limit only in sheep meat samples, but it probably not causing a tremendous health risk as the exceedance is negligible. Cu can increase in animal body if the consumed vegetable leafs have contaminated with $\mathrm{Cu}[8]$.

Both $\mathrm{Al}$ and $\mathrm{Fe}$ are effective exceeding the WHO guideline, as discussed in the first section high value of $\mathrm{Al}$ is due to the type of both animals' diet in the study area [17]. Fe is higher than the WHO standards in both animal meat samples, but it is very high in cows' meat samples as showed above. Both excessive and deficiency of Fe intake can lead to health disorder [32]. Fe is a naturally occurring element, but extreme high value as read in cow samples may be due to human intervention through the quality of air, water, or food that
TABLE 3: Comparison of study area with the WHO 2017 standards

\begin{tabular}{lccc} 
Elements & $\begin{array}{c}\text { WHO } \\
(\mathbf{p p b})\end{array}$ & $\begin{array}{c}\text { Study group } \\
\text { (sheep) }(\mathbf{p p b})\end{array}$ & $\begin{array}{c}\text { Study group } \\
(\mathbf{c o w}) \mathbf{( p p b )}\end{array}$ \\
\hline $\mathrm{Al}$ & 200 & 404.5 & 278.7 \\
$\mathrm{Fe}$ & $100-300$ & 474.1 & 3720 \\
$\mathrm{Hg}$ & $1-6$ & 26.91 & 26.78 \\
$\mathrm{Mn}$ & $100-400$ & 179.7 & 110.0 \\
$\mathrm{Zn}$ & 3000 & 1080 & 1688 \\
$\mathrm{As}$ & 10 & 7.478 & 6.256 \\
$\mathrm{Co}$ & 3 & 0.266 & 1.242 \\
$\mathrm{Cr}$ & 50 & 0.752 & 6.692 \\
$\mathrm{Cu}$ & 1000 & 1038 & 134.3 \\
\hline
\end{tabular}

This table is made based on Tables 1 and 2 and the WHO standards for heavy metals 2017

consumed by the animals, but there is no study regarding of air, water, or vegetation quality of the study area.

Furthermore, $\mathrm{Hg}$ which is a toxic elements [8], [9] is out of the WHO accepted range but with a high significant distance between the samples and the standard value. A previous study confirms this finding as mercury recorded high in beef meat in North Algeria [14]. However, $\mathrm{Hg}$ is a naturally accruing element, but a high value in the body can have a detrimental effect on health of the consumers [33], such as damaging nervous system, liver, and eyes, and infant may be deformed; other symptoms of mercury toxicity are a headache, fatigue, anxiety, lethargy, and loss of appetite.

\section{CONCLUSION}

The present findings indicated that these trace elements such as iron, cobalt, copper, zinc, arsenic, manganese, aluminum, mercury, and chromium were detected in all the samples. Only, $\mathrm{Hg}, \mathrm{Al}$, and $\mathrm{Fe}$, in both sheep and cows' meat, presented high values for both groups in comparison with allowed limits of the WHO 2017. However, overall, this study confirms that the cow and sheep meat still safe to eat in the study area because only $\mathrm{Al}, \mathrm{Fe}$, and $\mathrm{Hg}$ were found danger, but all other elements are complying with the global standards.

\section{ACKNOWLEDGMENT}

Our special thanks and much appreciation goes to the workers in slaughterhouses of Erbil and Koya, for their support and cooperation with the data collection.

We would like to thank Garmian University for testing the samples and Koya University for using its laboratories. 


\section{REFERENCES}

[1] A. Y. Ali, N. J. Hamad, and R. R. Hamadamin. "Assessment of the physical and chemical properties of groundwater resources in the Shewashok oil field". Koya University Journal, vol. 45, pp. 163-183, 2018.

[2] F. I. Ibitoye. "Ending natural gas flaring in Nigeria's oil fields". Journal of Sustainable Development, vol. 7, no. 3, p.13, 2014.

[3] M. Durkalec, J. Szkoda, R. Kolacz, S. Opalinski, A. Nawrocka and J. Zmudzki. "Bioaccumulation of lead, cadmium and mercury in roe deer and wild boars from areas with different levels of toxic metal pollution". International Journal of Environmental Research, vol. 9, no. 1, pp. 205-212, 2015.

[4] Q, Zhou, J. Zhang, J. Fu, J. Shi and G. Jiang. "Biomonitoring: An appealing tool for assessment of metal pollution in the aquatic ecosystem". Analytica Chimica Acta, vol. 606, no. 2, pp. 135-150, 2008.

[5] S. Stankovic, P. Kalaba and A. R. Stankovic. "Biota as toxic metal indicators". Environmental Chemistry Letters, vol. 12, no. 1, pp. 63-84, 2014

[6] C. N. Nwankwo and D. O. Ogagarue, D.O. "Effects of gas flaring on surface and ground waters in Delta State, Nigeria". Journal of Geology and Mining Research, vol. 3, no. 5, pp. 131-136, 2011.

[7] K. Ihesinachi and D. Eresiya. "Evaluation of heavy metals in orange, pineapple, avocado pear and pawpaw from a farm in Kaani, Bori, Rivers State Nigeria". International Journal of Environmental Research and Public Health, vol. 1, pp. 87-94, 2014.

[8] World Health Organization. "Trace Elements in Human Nutrition and Health". World Health Organization, Geneva, 1996.

[9] A. Mehri and R. F. Marjan. "Trace elements in human nutrition: A review". International Journal of Medical Investigation, vol. 2, pp. 115-28, 2013.

[10] R. Munoz-Olives and C. Camara. Speciation related to human health. In: L. Ebdon, L. Pitts, R. Cornelis, H. Crews, O. F. Donard and P. Quevauviller, editors. "Trace Element Speciation for Environment Food and Health". The Royal Society of Chemistry, Cambridge, pp. 331-353, 2001.

[11] Food and Agriculture Organization. Standard for contaminants and toxins in consumer products human and animal. In: "Codex Alimentarius". Food and Agriculture Organization, Geneva, pp. 193, 1995.

[12] A. Naqshabandy. "Regional Geography of Kurdistan-Iraq". $1^{\text {st }}$ ed. Braiaty Center, Erbil, pp. 74 -78, 1998.

[13] K. Sathyamoorthy, T. Sivaruban, and S. Barathy. "Assessment of heavy metal pollution and contaminants in the cattle meat". Journal of Industrial Pollution Control, vol. 32, no. 1, pp. 350-355, 2016.

[14] B. Badis, Z. Rachid and B. Esma. "Levels of selected heavy metals in fresh meat from cattle, sheep, chicken and camel produced in Algeria". Annual Research and Review in Biology, vol. 4, no. 8, p. 1260,2014

[15] O. Akoto, N. Bortey-Sam, S. M. Nakayama, Y. Ikenaka, E. Baidoo, Y. B. Yohannes, H. Mizukawa and M. Ishizuka. "Distribution of heavy metals in organs of sheep and goat reared in Obuasi: A gold mining town in Ghana". International Journal of Environmental Science and Technology, vol. 2, no. 2, pp. 81-89, 2014.

[16] M. Bettinelli, G. Beone, S. Spezia, and C. Baffi. "Determination of heavy metals in soils and sediments by microwave-assisted digestion and inductively coupled plasma optical emission spectrometry analysis". Analytica Chimica Acta, vol. 424, no. 2, pp. 289-296, 2000.

[17] O. Miedico, M. lammarino, G. Paglia, M. Tarallo, M. Mangiacotti and A. E. Chiaravalle. "Environmental monitoring of the area surrounding oil wells in Val d'Agri (Italy): Element accumulation in bovine and ovine organs". Environmental Monitoring and Assessment, vol. 188, no. 6, p. 338, 2016.

[18] J. Krupa and J. Swida. "Concentration of certain heavy metals in the muscles, liver and kidney of goats fattened in the Beiszczady mountains". Animal Science, vol. 15, pp. 55-59, 1997.

[19] M. Malarkodi, R. Krishnasamy, R. Kumaraperumal and T. Chitdeshwari. "Characterization of heavy metal contaminated soils of Coimbatore district in Tamilnadu". Agronomy Journal, vol. 6, pp. 147-151, 2007.

[20] Agency for Toxic Substances and Disease Registry. "Toxicological Profile for Chromium. Agency for Toxic Substances and Disease Registry". U.S. Department of Health and Human Services. Public Health Service, United States, pp. 263-278, 2012.

[21] P. Trumbo, A. A. Yates, S. Schlicker and M. Poos. "Dietary reference intakes: Vitamin A, vitamin K, arsenic, boron, chromium, copper, iodine, iron, manganese, molybdenum, nickel, silicon, vanadium, and zinc". Journal of the Academy of Nutrition and Dietetics, vol. 101, no. 3, p. 294, 2001.

[22] E. D. Andrews, B. J. Stephenson, J. P. Anderson and W. C. Faithful. "The effect of length of pasture on cobalt deficiency in lambs". New Zealand Journal of Agricultural Research, vol. 1, pp. 125-139, 1958.

[23] T. D. Luckey and B. Venugopal. "Metal Toxicity in Mammals". Plenum Press, New York, p. 25, 1977.

[24] O. M. Radostits, C. C. Gay, D. C. Blood and K. W. Hinchcliff. Doenças causadas por substâncias químicas inorgâncias e produtos químicos utilizados nas fazendas. In: O. M. Radostits, C. C. Gay, D. C. Blood and K. W. Hinchcliff, editors. "Clínica Veterinária: Um Tratado de Doenças dos Bovinos, Ovinos, Suínos, Caprinos E Equinos". Guanabara Koogan, Rio de Janeiro, pp. 1417-1471, 2002.

[25] E. Manno, D. Varrrica and G. Dongarra. "Metal distribution in road dust samples collected in an urban area close to a petrochemical plant at Gela, Sicily". Atmospheric Environment, vol. 40, pp. 59295941, 2006.

[26] P. Ponka, M. Tenenbein and J. W. Eaton. Iron. In: G. F. Nordberg, B. A. Fowler, M. Nordberg and L. T. Friberg, editors. "Handbook on the Toxicology of Metals". Academic Press, San Diego, vol. 30, pp. 577-598, 2007.

[27] F. Zhang, X. Yan, C. Zeng, M. Zhang, S. Shrestha, L.P. Devkota and T. Yao. "Influence of traffic activity on heavy metal concentration of roadside farmland soil in Mountainous areas". International Journal of Environmental Research and Public Health, vol. 9, pp. 1715-1731, 2012a.

[28] L. Johrem, B. Sundstrom, C. Astrand and G. Haegglund. "The levels of zinc, copper, manganese, selenium, chromium, nickel, cobalt and aluminium in the meat, liver and kidney of Swedisch pigs and cattle". Zeitschrift für LeObensmittel-Untersuchung und -Forschung, vol. 188, pp. 39-44, 1989.

[29] J. Falandysz. "Some toxic and essential trace metals in cattle from the northern part of Poland". Science of the Total Environment, vol. 136, pp. 177-191, 1993.

[30] World Health Organization. "Guidelines for Drinking-Water Quality: 
Maamun Qadir Salih, et al.: Shewashok Oil Field Impacts on Environment

Incorporating First Addendum". World Health Organization, Geneva, 2017.

[31] World Health Organization. "Guidelines for Drinking-Water Quality: Recommendations". World Health Organization, Geneva, 2004.

[32] G. Nordberg, B. A. Fowler and M. Nordberg. "Handbook on the
Toxicology of Metals". Academic Press is an Imprint of Elsevier, London, 2014.

[33] K. M. Rice, E. M. Walker Jr., M. Wu, C, Gillette and E. R. Blough. "Environmental mercury and its toxic effects". Journal of Preventive Medicine and Public Health, vol. 47, no. 2, pp. 74, 2014. 